\title{
O brasileiro como estrangeiro: a política migratória brasileira para emigrantes
}

\author{
Brazilians as strangers: the brazilian migration policy \\ for emigrants
}

\author{
Ana Paula Martins Amaral \\ Universidade Federal de Mato Grosso do Sul \\ Luiz Rosado Costa \\ Universidade Federal de Mato Grosso do Sul \\ Cristiane Batista Arrua Allgayer \\ Universidade Federal de Mato Grosso do Sul
}

Resumo Até a década de 1980, a política migratória brasileira foi pautada pela ótica exclusiva de país de destino, situação que se modificou com a emergência, a partir daquela década, de significativos fluxos migratórios brasileiros para fora do país em decorrência da estagnação econômica e desemprego então vigentes, associados ao aumento das facilidades de transporte e informação. Esses fluxos emigratórios prologam-se até os dias atuais e o Brasil, a partir de então, desenvolveu, gradativamente, uma política migratória voltada para os brasileiros no exterior. Esta pesquisa, descritiva e exploratória, valendo-se dos métodos bibliográfico e documental, visa a analisar como se deu a relação entre o Estado brasileiro e os seus emigrantes, limitada aos planos participativo e institucional, durante a vigência do Estatuto do Estrangeiro, que tratou apenas da imigração em seus dispositivos. Propõe-se também a estudar a nova perspectiva de inclusão dos emigrantes e de manutenção de seus vínculos jurídico-políticos com o Brasil trazidos pela nova Lei de Migração, que entrará em vigor em 21 de novembro de 2017, e será o primeiro marco legal brasileiro a respeito de emigração.

Palavras-chave: POLÍTICA MIGRATÓRIA BRASILEIRA; EMIGRAÇÃO; LEI 13.445/2017. 
Abstract Until the 1980s, Brazilian migration policy was based on the exclusive view of the destination country, a situation that changed with the emergence, from that decade, of significant Brazilian migratory flows out of the country due to economic stagnation and unemployment associated with the increase of transport and information facilities. These migratory flows continue until nowadays and Brazil, from then on, gradually developed a migratory policy directed to Brazilians abroad. This research, descriptive and exploratory, using the bibliographic and documentary methods, has the objective of analyzing how the relationship between the Brazilian State and its emigrants, limited to the participatory and institutional plans, during the validity of the Alien Statute, which dealt only of immigration on their devices. It also has the objective of studying the new perspective of inclusion of migrants and the maintenance of their juridical-political ties with Brazil brought by the new Migration Law, which will come into effect on November 21st, 2017 and previews public policies to emigrants.

Key-words: Brazilian migration policy; Emigration; LaW $\mathrm{N}$. $13.445 / 2017$.

\section{INTRODUÇÃO}

Especialmente na última metade do século XIX e início do século $\mathrm{XX}$, o Brasil foi o destino de milhares de imigrantes. Esses fluxos migratórios ao longo do século XX e XXI diminuíram, mas não cessaram, e a partir da década de 1980 o Brasil também deixou de ser apenas encarado como país de destino para tornar-se país de origem de significativos fluxos migratórios.

A partir desses significativos fluxos emigratórios, que demandaram ação governamental com vistas a assistir às comunidades brasileiras que se formavam no exterior desenvolveu-se, gradativamente, uma política migratória voltada para os brasileiros emigrados, que culminou com a aprovação da Lei 13.445/2017, sancionada em 24 de maio de 2017, que traz um capítulo voltado aos emigrantes e trata das migra- 
ções como tema integrado e sob a ótica de um país de trânsito, origem e destino, como é atualmente o Brasil.

O presente trabalho, descritivo e exploratório, por meio dos métodos de pesquisa bibliográfica e documental, visa a analisar o desenvolvimento da política migratória do Estado brasileiro para os seus emigrantes, por intermédio da análise de sua atuação diplomática e consular e dos marcos legais que trataram do tema. Para tanto, utiliza-se como marcos teóricos principais os autores Luís Renato Vedovato, Marcia Anita Sprandel, Rossana Rocha Reis, Maria Rita Fontes Faria, Maxine Margolis.

Divide-se, assim, a pesquisa em três partes: inicialmente abordamos os antecedentes históricos da transição do Brasil como país de destino para país de origem de fluxos migratórios significativos; em seguida se observa a política migratória para emigrantes desenvolvida na vigência da Lei 6.815/1980 (Estatuto do Estrangeiro), que não contemplou a emigração em seus dispositivos e, por fim, analisam-se as perspectivas abertas pela Lei $\mathrm{n}^{\circ}$. 13.445/2017, quando da sua entrada em vigor em 21 de novembro de 2017 após o período de vacatio legis, que será a primeira Lei migratória brasileira a tratar, além da imigração, também da emigração, prevendo direitos e políticas públicas para emigrantes.

\section{AnTECEDENTES: O BRASIL de PAÍS DE DESTINO A PAÍS DE ORIGEM}

O marco inicial da emigração de brasileiros pode ser situado na década de 1970, quando os chamados "brasiguaios"1 cruzaram as fronteiras do vizinho Paraguai em busca de terras, impulsionados pelos incentivos dados pelo governo de Alfredo Stroessner à imigração brasileira. Essa emigração, todavia, permaneceu "invisível" ao Estado brasileiro e "a presença de milhares de brasileiros no Paraguai só foi assumida pelo governo militar quando grupos organizados começaram a retornar ao Brasil no começo da década de 1980" (SPRANDEL, 2010, p. 306).

1 O termo foi criado, em 1985, quando do retorno do primeiro grupo organizado de brasileiros do Paraguai devido aos conflitos agrários que se desencadearam naquele país. 
Na década de 1980, o fluxo migratório de brasileiros para o exterior, que até então dirigia-se predominantemente para o Paraguai, aumentou e se diversificou: os brasileiros a partir dessa década dirigemse, sobretudo, para os EUA, Europa e Japão. Até então, a política migratória brasileira era vista pela ótica praticamente exclusiva de país de destino, situação que se modificou com a emergência desses fluxos migratórios brasileiros para fora do país:

A partir da década de 80, o aumento das facilidades de informação e transporte intercontinental, associados ao processo de globalização, conjugou-se a quadro doméstico de estagnação econômica e desemprego, o que acabou por desencadear o início de correntes emigratórias que se prolongam até os dias atuais (FARIA, 2015, p. 66).

Foi, assim, na década de 1980 que o Brasil iniciou a transição de país predominantemente de destino para país predominantemente de origem de migrantes.

Com esses novos fluxos, progressivamente, a política migratória passou a levar em consideração, também, os emigrantes, situando o Brasil entre os países de origem. Rossana Rocha Reis (2011, p. 61) elenca os fatores que teriam contribuído para sensibilizar o Estado às demandas dos brasileiros no exterior: "a importante contribuição financeira dos emigrantes, sua participação política e a repercussão de casos de discriminação contra brasileiros no exterior sem dúvida contribuíram para tornar o Estado mais sensível às demandas do grupo".

A mobilização dos brasileiros no exterior na luta e reivindicação por direitos de cidadania também desempenhou importante papel para que o Estado brasileiro voltasse sua atenção para os seus emigrantes. Nesse sentido, pode-se mencionar como exemplo a Casa do Brasil de Lisboa, associação civil fundada, em 1992, por brasileiros e portugueses que viveram no Brasil, que tem atuado ativamente em prol dos direitos dos emigrantes brasileiros em Portugal junto aos governos dos dois países.

Dados recentes confirmam a permanência destes fatores: no plano econômico, estima-se, no perfil migratório brasileiro de 2009, apre- 
sentado pela Organização Internacional para as Migrações (OIM), que o Brasil tornou-se o segundo maior receptor de remessas do exterior, atrás apenas do México, recebendo quantias superiores a U\$5 bilhões por ano (OIM, 2010); no plano político, o Tribunal Superior Eleitoral aponta uma crescente inscrição de eleitores no exterior - nas eleições de 2010 votaram 200.392 brasileiros residentes no exterior, enquanto que nas eleições de 2014 encontravam-se inscritos 337.168 eleitores aptos a votar (BRASIL, 2014) e quanto a caso de discriminação de brasileiros no exterior pode ser citado o caso de Jean Charles de Menezes, assassinado pela polícia inglesa ao ser confundido com um terrorista em Londres, em 22 de julho de $2005,{ }^{2}$ e a sucessiva retenção de brasileiros em aeroportos espanhóis em 2008, que gerou a "crise dos inadmitidos".

\section{A política migratória para EMigrantes NA VigênCIA do Estatuto do Estrangeiro (1980-2017)}

O Estatuto do Estrangeiro, ainda em vigor, foi elaborado em um contexto no qual o Brasil era visto apenas como país de chegada - o Estatuto foi sancionado em 19 de agosto de 1980, e o Brasil tornou-se país predominantemente de saída, como já ressaltado, apenas em meados daquela década -, por essa razão, os emigrantes não foram por ele considerados e o CNIg foi criado como conselho nacional de imigração, e não de migração, como seria mais adequado a um país de destino, trânsito e origem como se tornou o Brasil.

Embora sem uma lei de migração que tratasse também da emigração, diante do crescente volume de emigrantes, o Brasil passou a ter interesse na manutenção do vínculo político-jurídico de nacionalidade com os brasileiros no exterior e desenvolveu sua política migratória para emigrantes, principalmente nos planos institucional, por meio da atuação do Itamaraty, e participativo, visando à inclusão e integração dos emigrantes.

2 O caso chegou a ganhar uma versão cinematográfica, em 2009, o longametragem "Jean Charles", dirigido por Henrique Goldman e estrelado por Selton Melo. 


\subsection{Nacionalidade brasileira e emigração: as emendas constitucionais}

O novo contexto de emigrações, que trouxe a discussão sobre a necessidade de manutenção do vínculo do Estado brasileiro com os seus cidadãos emigrados, levou à alteração do texto constitucional, a fim de que os brasileiros residentes no exterior não fossem mais forçados a renunciar à nacionalidade brasileira para adquirir a do país que estavam residindo: a Constituição brasileira de 1988, em seu texto original, não admitia a dupla nacionalidade e determinava a perda da nacionalidade brasileira àqueles que se naturalizassem em outro país.

Apenas a partir da Emenda Constitucional de Revisão no . 3, de 7 de junho de 1994 - que inseriu o inciso II ao $\S 4^{\circ}$. do artigo 12 do texto constitucional - foi permitida a aquisição de dupla nacionalidade pelos brasileiros.

A referida emenda, todavia, em que pese tenha possibilitado a dupla nacionalidade, suprimiu a possibilidade de registro nas repartições consulares e diplomáticas dos filhos de brasileiros nascidos no exterior: o texto da Emenda suprimiu, inexplicavelmente, a expressão "sejam registrados em repartição brasileira competente" do artigo 12, I, "c"3 (BRASIL, 1994), da Constituição e, assim, condicionou a aquisição da nacionalidade brasileira aos nascidos no estrangeiro, mas filhos de brasileiros, à residência no Brasil.

O dispositivo constitucional ficou, a partir da emenda de revisão, com o seguinte texto:

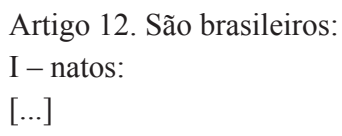

Artigo 12. São brasileiros:

I - natos:

$[\ldots]$

3 A redação original do dispositivo constitucional era: Art 12. São brasileiros: I - natos: [...] c) os nascidos no estrangeiro, de pai brasileiro ou de mãe brasileira, desde que sejam registrados em repartição brasileira competente, ou venham a residir na República Federativa do Brasil antes da maioridade e, alcançada esta, optem, em qualquer tempo, pela nacionalidade brasileira. 
c) os nascidos no estrangeiro, de pai brasileiro ou mãe brasileira, desde que venham a residir na República Federativa do Brasil e optem, em qualquer tempo, pela nacionalidade brasileira (BRASIL, 1994).

Assim, essas crianças nascidas no exterior permaneceriam na condição de apátridas se nascidas em países que adotam apenas o critério do jus sanguinis para o reconhecimento da nacionalidade, até que viessem um dia residir no Brasil, o que levou um grupo de emigrantes a se mobilizar para combater essa alteração:

Contra essa medida um grupo de emigrantes brasileiros na Suíça criou o "Movimento Brasileirinhos" ou "Brasileirinhos Apátridas", que coordenou, via Internet, mobilizações em Washington, Tel Aviv, Zurique, Paris, Londres e Nagoya (SPRANDEL, 2010, p. 311).

A questão dos "brasileirinhos apátridas" foi resolvida em 2007, com a promulgação da Emenda Constitucional $n^{\circ}$. 54 (BRASIL, 2007) e ilustra a importância da mobilização dos emigrantes para a formulação de uma política migratória que lhes considere. A nova Emenda, além de acrescentar no artigo 12, I, "c" da Constituição, a possibilidade, suprimida pela Emenda de Revisão n ${ }^{\circ}$. 3, de que os filhos de brasileiros nascidos no exterior adquirissem a nacionalidade brasileira se registrados em repartição consular ou diplomática competente, permitiu, retroativamente, o registro dos filhos de brasileiros nascidos no exterior entre 7 de junho de 1994 e 20 de setembro de 2007, data de promulgação da Emenda $\mathrm{n}^{\circ}$. 54, ao acrescer o artigo 95 ao Ato das Disposições Constitucionais Transitórias.

\subsection{Desenvolvimento de uma política migratória para emigrantes}

Conforme já destacado, o marco legal em vigor sobre migrações, o Estatuto do Estrangeiro, tratou o fenômeno migratório apenas sob a ótica de país de destino. Assim, até a entrada em vigor do Decreto 
$\mathrm{n}^{\mathrm{o}}$. 7.214/2010, a política migratória brasileira para os brasileiros no exterior ficou restrita a ações pontuais, não guiadas por uma política de governo mais ampla que fixasse suas bases.

Dando início às ações consulares mais gerais, voltadas para as comunidades brasileiras no exterior, foi lançado pelo governo brasileiro, em 1995, o "Programa de Apoio aos Brasileiros no Exterior", que criou os consulados itinerantes para prestarem assistência aos brasileiros nas regiões em que sua presença era crescente. Nas palavras do então presidente Fernando Henrique Cardoso (2002, p. 547), quando do lançamento do programa em 8 de novembro de 1995: "temos agora um consulado itinerante. Quer dizer, é o Governo que vai ao brasileiro que está lá fora, não é o brasileiro que vem até o Governo".

Como consequência da maior organização dos emigrantes brasileiros para pleitear por políticas de apoio e da necessidade da formulação de uma política governamental para as comunidades brasileiras no exterior, foi editado o Decreto $n^{\circ}$. 7.214, de 15 de junho de 2010, que passou a balizar a diplomacia consular no assunto ao estabelecer os princípios e diretrizes da política brasileira para as comunidades brasileiras no exterior, além de ter instituído, no plano participativo, as Conferências Brasileiras no Mundo - CBM e criado o Conselho de Representantes de Brasileiros no Exterior - CRBE.

Entre os diversos princípios e diretrizes elencados no artigo $1^{\circ}$. do Decreto, destacam-se os seguintes:

I - pleno direito de locomoção dos brasileiros, respeitadas as normas legais e regulamentares cabíveis; $[\ldots]$

III - aumento da interação entre o Ministério das Relações Exteriores e os brasileiros que vivem fora do Brasil;

IV - promoção do autodesenvolvimento e de melhores condições de vida aos brasileiros que vivem no exterior, inclusive mediante a prestação de serviços consulares de segunda geração, como nas áreas de educação, saúde, trabalho, previdência social e cultura; 


\begin{abstract}
$[\ldots]$
VIII - realização de parcerias para aproveitamento do potencial dos brasileiros no exterior, com destaque para comunidades específicas, tais como científica, cultural, jurídica, política e esportiva, com o objetivo de promover o Brasil, sua cultura e seus produtos;

IX - atuação diplomática, nos âmbitos bilateral, regional e multilateral, em defesa dos legítimos direitos dos emigrados e viajantes brasileiros, com base no direito internacional;

$\mathrm{X}$ - articulação da política para as comunidades brasileiras no exterior com as políticas emigratórias e imigratórias que venham a ser desenvolvidas pelo governo brasileiro (BRASIL, 2010).
\end{abstract}

Assim, apenas a partir do Decreto $n^{\circ}$. 7.214/2010, quase 30 anos após a "diáspora brasileira", o Brasil passou a ter oficialmente uma política migratória voltada para os seus emigrantes. Essa política migratória, todavia, elaborada por um Decreto, sofre limitações por parte do Estatuto dos Estrangeiros ainda em vigor até que transcorra o período de vacatio da nova Lei de Migração.

Como ressaltado, no plano interno, a legislação brasileira que regulamenta as migrações internacionais, como já abordado, é a Lei $6.815 / 80$, que elaborada no contexto da guerra fria e durante a vigência de um regime político autoritário, traz uma série de restrições aos direitos dos imigrantes. Conforme destaca Vedovato (2013, p. 127): “por ter nascido em período ditatorial [a Lei 6.815/1980] dá ao estrangeiro um tratamento de exclusão. Seus dispositivos são meios para proteção do Estado diante de uma possível 'ameaça estrangeira"'.

Esse tratamento da imigração como questão de segurança nacional, e não de direitos humanos, traz dificuldade à reivindicação de respeito aos direitos dos brasileiros que se encontram no exterior: "a inconsistência da legislação de 1980 é apontada como um ponto fraco das demandas do Estado brasileiro para tratar a questão dos emigrantes brasileiros em negociações e fóruns bilaterais e multilaterais" (REIS, 2011, p. 59). 
Nesse sentido, fica difícil reivindicar, no plano da reciprocidade, o "pleno direito de locomoção dos brasileiros, respeitadas as normas legais e regulamentares cabíveis", como previsto no inciso I do artigo $1^{\circ}$. do Decreto $n^{\circ}$. 7.214/2010, se o Brasil não assegura esse mesmo direito em sua legislação vigente para os imigrantes.

Assim, a adoção pelo Brasil de uma legislação migratória menos restritiva e com foco nos Direitos Humanos acabará por beneficiar não só os estrangeiros que no Brasil venham morar, mas também os brasileiros que se tornem estrangeiros ao migrar para o exterior.

\subsection{A atuação do Brasil nos planos multilateral e bilateral em defesa de seus emigrantes}

A inserção dos brasileiros no mercado de trabalho dos países de destino é dificultada, principalmente, por três fatores, que pautam a atuação do Itamaraty: status migratório irregular, dificuldade de acesso à informação sobre seus direitos e baixa educação formal (SANTOS, 2015, p. 72).

Os consulados, antes focados em assuntos de natureza comercial, cartorial e de concessão de vistos, passaram a desempenhar, a partir da "diáspora brasileira", uma importante função de apoio aos brasileiros residentes em outros países.

\subsubsection{Situação migratória irregular}

Há um elevado índice de migrantes brasileiros em situação de irregularidade (OIM, 2010), o que leva o Brasil a destacar no plano externo a garantia dos direitos humanos de seus emigrantes, que pela indocumentação ficam em situação de vulnerabilidade:

A ênfase na promoção dos direitos humanos revela-se elemento particularmente importante da política governamental do Brasil para os brasileiros no exterior, haja vista a irregularidade migratória de grande parcela dos migrantes brasileiros. A premência de se salvaguardar os direitos humanos dos migrantes, independentemen- 
te de sua condição migratória, impulsiona, assim, a atuação brasileira nos foros regionais e multilaterais de negociações sobre migrações (FARIA, 2015, p. 74).

Nesse contexto, em 7 de junho de 2011, o Brasil, para firmar sua posição de defesa dos Direitos Humanos no contexto das migrações, com a Argentina, Paraguai e Uruguai solicitou Parecer Consultivo à Corte Interamericana de Direitos Humanos (CoIDH), a fim de que fosse determinado "com maior precisão quais são as obrigações dos Estados com relação às medidas passíveis de serem adotadas a respeito de meninos e meninas, associadas à sua condição migratória, ou à de seus pais" (CoIDH, 2014). A solicitação conjunta resultou na Opinião Consultiva $\mathrm{n}^{\circ} .21$, datada de 19 de agosto de 2014, onde a Corte estabeleceu o alcance dos direitos das crianças no contexto das migrações, levando em consideração o superior interesse da criança e a dupla situação de vulnerabilidade a que os meninos e meninas migrantes estão submetidos: a primeira pela situação de migrantes e a segunda pela própria condição de crianças, que os torna suscetíveis a violações específicas de direitos humanos em razão da idade.

Apesar de sua ênfase na proteção de Direitos Humanos no plano internacional, são bastante limitadas, porém, as medidas práticas que o Estado brasileiro pode tomar no sentido de regularizar a situação dos brasileiros indocumentados, pois se inserem no âmbito das soberanias nacionais as políticas migratórias e os critérios para o ingresso e fixação no território dos Estados.

Nesse sentido, a atuação do Itamaraty limita-se principalmente à atividade informativa de divulgar as oportunidades de regularização do status migratório, como as anistias, quando surgirem e orientar os emigrantes sobre o seu procedimento.

\subsubsection{Dificuldade de acesso à informação}

A dificuldade de acesso à informação sobre os seus direitos, acentuada muitas vezes pelo desconhecimento adequado da língua do país de destino, propicia a exploração dos trabalhadores brasileiros. 
Assim, visando a orientá-los sobre os seus direitos trabalhistas e oportunidades no mercado de trabalho local foi organizada a "Semana do Trabalhador Brasileiro", que já teve edições no Japão, Estados Unidos e Portugal:

As palestras são divididas em dois grupos: (i) orientação sobre legislação e mercado de trabalho local para os brasileiros que desejam permanecer no exterior e (ii) orientação para os brasileiros que desejam retornar ao Brasil (SANTOS, 2015, p. 74).

Alguns consulados têm ainda tomado iniciativas específicas em suas regiões, por exemplo, o Consulado-Geral do Brasil em Hamamatsu, Japão, que criou o "Espaço do Trabalhador Brasileiro" (BRASIL, 2016) para orientar os emigrantes sobre as questões trabalhistas e previdenciárias, divulgar informações acerca do mercado de trabalho no Brasil e Japão, além de divulgar informações a respeito de cursos de capacitação e de formação profissional disponível em ambos os países.

Foram elaboradas ainda diversas cartilhas, disponíveis no portal "Brasileiros no Mundo" do Itamaraty na Internet (BRASIL, 2017), visando a orientar os emigrantes acerca dos seus direitos, a respeito de como obter assistência consular e ainda para prevenir que se tornem vítimas de crimes, como o tráfico de pessoas.

Por intermédio da informação, assim, visa o Estado brasileiro a reduzir a exploração de seus nacionais no exterior e, ao mesmo tempo, orientá-los sobre possíveis investimentos do dinheiro que juntaram quando da volta para o Brasil.

\subsubsection{Baixa escolaridade}

Mesmo o emigrante com educação formal completa pode encontrar dificuldades em alocar-se profissionalmente no exterior e, muitas vezes, acaba exercendo atividade profissional aquém de sua qualificação e que não exerceria no Brasil, quadro que se agrava em relação aos que possuem baixa escolaridade, restando-lhes os serviços que os pró- 
prios nacionais do país de destino evitam, os chamados pelos japoneses de 3K: kitui, kitanai e kiken - árduos, sujos e perigosos, respectivamente (MARGOLIS, 2013).

Assim, visando à promoção do autodesenvolvimento e de melhores condições de vida aos brasileiros que vivem no exterior - que inclui a prestação de serviços consulares na área de educação conforme prevê o inciso IV, do artigo $1^{\circ}$., do Decreto 7.214/2010 - o Itamaraty fez parceria com o Ministério da Educação para que fossem oferecidos cursos preparatórios e fosse aplicado no exterior o Exame Nacional para Certificação de Competências de Jovens e Adultos (ENCCEJA), o antigo supletivo, voltado àqueles que não tiveram oportunidade de concluir os seus estudos em idade própria.

Em 2001, foi realizada a primeira edição do ENCCEJA e na edição de 2017, o ENCCEJA Exterior foi aplicado por consulados brasileiros em dez países: EUA, Guiana Francesa, Portugal, Bélgica, Suíça, Espanha, Reino Unido, França, Holanda e Japão (BRASIL, 2017).

$\mathrm{Na}$ área da educação, o Itamaraty atua também divulgando cursos profissionalizantes, oferecidos nas modalidades presencial e a distância, pelo SEBRAE, SENAC e SENAI.

\subsubsection{Previdência social e a emigração}

A fim de que possam ser somados os tempos de contribuição do trabalhador brasileiro no Brasil e no país para o qual emigrou, foram assinados, recentemente, a partir de negociações feitas pelo Itamaraty e Ministério da Previdência Social, acordos bilaterais na área previdenciária com alguns dos principais países receptores de brasileiros, por exemplo, EUA (em processo de ratificação), França, no ano de 2014, Japão, no ano de 2012, Alemanha, no ano de 2009, Portugal e Espanha, ambos no ano de 1995 (BRASIL, 2013).

No plano multilateral, há dois acordos em vigor no Brasil: o Acordo Multilateral de Seguridade Social do Mercado Comum do Sul e o seu regulamento administrativo, promulgado pelo Decreto $\mathrm{n}^{\circ} .5 .722$, de 13 de março de 2006, e a Convenção Multilateral Ibero-Americana de Seguridade Social, promulgada pelo Decreto 8.358, de 13 de novembro 
de 2014, que tem Bolívia, Brasil, Chile, El Salvador, Equador, Espanha, Paraguai, Portugal e Uruguai como signatários.

Os acordos internacionais previdenciários são importantes instrumentos para a garantia de direitos sociais, como a pensão por morte e aposentadoria, do cidadão brasileiro que trabalhou em outro país e os seus dependentes e também dos imigrantes que trabalharam no Brasil.

\section{Política Migratória para Emigrantes na Nova Lei de MigraÇÃo (Lel Nº 13.445, de 24 de MAio de 2017)}

A Nova Lei da Migração pode ser considerada como um avanço no campo dos direitos humanos e da política migratória brasileira. Aprovada no dia 18 de abril de 2017, seu texto mostra o interesse da reversão de pontos arenosos, como a personalidade militarista ainda identificável no Estatuto do Estrangeiro. Reflete um movimento de atualização e de aproximação às pautas de direitos e questões humanitárias mundialmente consolidadas. A partir do próprio título comum, a nova lei sinaliza os seus interesses a partir de uma própria e interna renovação conceitual: não mais se refere ao termo estrangeiro, mas sim ao termo imigrante.

Assim como a história de acolhimento migratório brasileiro é significativa, a presença dos brasileiros pelo mundo apresenta uma questão quantitativa de vulto. No reconhecimento da problemática desses cidadãos em sua acolhida em diversos países e em busca de uma reciprocidade positiva, a Nova Lei da Migração procura consolidar uma cultura de acolhimento.

Galeano (2009) observa que, embora o sonho migratório seja formado de uma perspectiva quase ilusória de um cidadão do mundo, que pode acessar a todos os países e espaços, a realidade dos emigrantes costuma ser bastante distinta. As normas fronteiriças e as limitações legais são portas que conferem traços distintos à difusão dos cidadãos pelo mundo.

Em uma analogia ao pensamento galeanista, o Estatuto do Estrangeiro e os seus efeitos em vigor foram reforços importantes para a que- 
bra da utopia migratória dos brasileiros pelo mundo, constituindo uma cultura de tratamento negativamente recíproca à legalmente estabelecida. Se não ocorria na prática esse tratamento mais endurecido, na perspectiva legal, normativa, ele era rigoroso, restritivo e bem estabelecido na Lei de 1980. Isso, por si, foi o suficiente para a constituição de uma série de problemas que envolveram e ainda envolvem os emigrantes brasileiros pelo mundo.

Todo o trabalho e o perfil da Nova Lei de Migração residem na reversão dos efeitos deletérios dessa experiência inicial. A nova normativa dá atenção especial aos brasileiros fora do país pela representatividade dessa população e pela reorganização do trato migratório. Se antes mesmo o termo emigrante não era tratado no Estatuto do Estrangeiro (BRASIL, 1980), a Nova Lei da Migração brasileira dedicou espaço específico para a sua proteção e tratamento das problemáticas envolvidas em seus direitos, deveres e garantias, dedicando-lhes um capítulo próprio.

O primeiro sinalizador dessa atenção pode ser identificado já no artigo $1^{\circ}$., que em seu $\S 1^{\circ}$., I, apresenta a conceituação do termo, como "emigrante: brasileiro que se estabelece temporária ou definitivamente no exterior" (BRASIL, 2017).

Os brasileiros de permanência temporária ou definitiva fora do país são um grupo representativo mundialmente. Na estimativa de Motoki et al. (2012), por volta de 1 a 3 milhões de brasileiros estão fora do país, distribuídos em cerca de 130 países. Os principais destinos selecionados são também aqueles que apresentam melhores perspectivas sociais e econômicas de vida, como Estados Unidos, Portugal e Espanha. Junto ao Paraguai, esse grupo de quatro países comporta pelo menos $60 \%$ dos emigrantes brasileiros. Conforme destaca Vedovato (2013, p. 124):

Ë possível também se verificar que houve uma diversificação de origem, não somente de destinos. Para melhor entender, é oportuno dizer que, em 2006, além de Minas Gerais, outros Estados já constituíam regiões de origem de migrantes: Espírito Santo, São Paulo, Mato Grosso do Sul, Santa Catarina, Paraná, Goiás e Rondônia. Essa quantidade de brasileiros no exterior 
causou um aumento no fluxo de remessa de dinheiro ao Brasil. Os valores estimados pelo Banco Interamericano de Desenvolvimento (BIRD - ou Banco Mundial) para 2005 situaram-se em torno de US\$ 6,4 bilhões.

Para se adaptar a essa mudança de perfil, em 2007 o Ministério das Relações Exteriores implantou a Subsecretaria-Geral das Comunidades Brasileiras no Exterior (VEDOVATO, 2013, p. 124).

Da total exclusão de tratamento da lei anterior (BRASIL, 1980) à reserva de espaços próprios com políticas públicas e espaços de garantia de direitos, a Nova Lei de Migração brasileira partiu da consideração de aspectos como Direitos Humanos e garantias fundamentais para assegurar a constituição da sua apresentação. Se antes havia um perfil rigoroso, competitivo e que priorizava a soberania nacional em primeiro plano, o perfil atual é mais maleável e aberto aos aspectos humanistas e à concepção das necessidades daqueles que deixam a sua pátria em busca de objetivos diversos. Dessa forma, consolidando esse interesse, a Seção II da Nova Lei de Migração, assevera no artigo $3^{\circ}$., dentro dos princípios e diretrizes que formam a política migratória do país, que será oferecida "XIX - proteção ao brasileiro no exterior" (BRASIL, 2017).

Essas garantias são expressivas para a formação de uma situação mais responsiva às necessidades dos brasileiros pelo mundo. A nova lei se apresenta em um momento em que os objetivos e perfis nas escolhas de emigração brasileira se remodelam. Houve uma redução para a escolha de partida para a Espanha entre 2010 a 2014, com avanço de cerca de $1,5 \%$ na migração para destinos estadunidenses, a partir do Visto Eb5, que oferece cidadania norte-americana desde que haja também investimento de US\$ 500 mil em projetos chancelados pelo governo. Um avanço que pode ser considerado tímido. No entanto, é crescente o interesse em países como o Canadá, com aberta política de incentivo para a questão migratória, que tem ainda como retorno bons resultados econômicos no desenvolvimento plural do mercado de trabalho e avanços sociais representativos ilustrados especialmente pelos benefícios do multiculturalismo (PÁDUA, 2015). 
Mas ainda, como um mapa da acolhida brasileira, Lacerda (2014) informa que a América do Norte é o destino determinante (com cerca de 1,4 milhão de brasileiros), a América do Sul (com 400 mil) e a Europa (com 212 mil). Em geral, os brasileiros desenvolvem nesses países postos de trabalho chamados de secundários. São aqueles que, pela cultura local, recebem rechaço social na ocupação por nativos (como o trabalho em clínicas, lanchonetes, serviços de táxi e similares). Apesar de ser dessa forma, a recepção dos emigrantes brasileiros nesses países nem sempre é amistosa ou simplificada.

Então, a Nova Lei da Migração brasileira se interessa em retirar a cultura que foi constituída a partir das inspirações do Estatuto do Estrangeiro de 1980, que tinha a natureza militarista, conforme discutido por Nicoli (2011, p. 92):

Sobre o panorama em que foi concebido o diploma, é importante relembrar que no final da década de 1970 e início dos anos 80 o Brasil já não era mais o destino de grandes contingentes de migrantes europeus, como fora no início e meados do século XX.

$[\ldots]$

Ao mesmo tempo, a imigração clandestina começou a se revelar como um problema, por conta do contexto de instabilidades sul-americanas.

$[\ldots]$

A tentativa de impor limites a estes indesejáveis fluxos de imigração irregular nos anos 80 resultou, assim, em uma lei de caráter restritivo, no contexto de uma ditadura militar que operava como de "segurança nacional" de maneira extremamente autoritária.

No interesse da reversão de uma cultura militarista, autoritária e restritiva, o tratamento do emigrante brasileiro é orientado especialmente a partir da Seção I, Das Políticas Públicas para os Emigrantes, em que são previstos seis fundamentos essenciais para atender aos problemas que atingem a esses brasileiros. 
A primeira questão prevista é a garantia, pelo artigo 77, I, de "proteção e prestação de assistência consular por meio das representações do Brasil no exterior" (BRASIL, 2017). Sabe-se que os consulados são importantes aportes para a resolução de problemas que envolvem os indivíduos das pátrias que representam, mediando os interesses e situações a fim de que atinjam a melhor resolução. Muitas vezes, fora de seu país de origem, emigrantes podem ter dificuldades em articular uma rede de apoio para atender a essas necessidades ou mesmo informar e, em casos como mortes ou crimes, são também importantes elos de mediação tempestiva às demandas apresentadas. Em uma visão mais ampla do atendimento e das funções consulares, o mesmo artigo, II, facilita o acesso às possibilidades de serviços consulares voltados a questões fundamentais, tais como "[...] educação, saúde, trabalho, previdência social e cultura" (BRASIL, 2017).

As questões que envolvem a emigração de brasileiros pelo mundo muitas vezes são conhecidas formalmente de maneira reducionista. Como os ingressos ilegais e demais questões de restrição ocorrem sob o manto da invisibilidade por envolverem condutas que extrapolam a lei, o incentivo de estudos e aproximações a essas realidades e suas possibilidades mitigativas são questões de dignidade. Para cobrir legalmente o desenvolvimento e a garantia de conhecimento e abordagem mais ampla da questão, o artigo 77, III, prevê também "promoção de estudos e pesquisas sobre os emigrantes e as comunidades de brasileiros no exterior, a fim de subsidiar a formulação de políticas públicas" (BRASIL, 2017).

Os emigrantes têm em seus direitos um dos principais alvos atingidos quando se envolvem nas questões migratórias. A distância de seu país de origem e os conflitos que podem se insculpir nas questões que envolvem problemas durante a experiência de emigração - quer na ilegalidade, criminalidade ou necessidades diversas - são abordadas pela previsão de que o emigrante terá, conforme o artigo 77, IV, a recepção de "atuação diplomática, nos âmbitos bilateral, regional e multilateral, em defesa dos direitos [...], conforme o direito internacional" (BRASIL, 2017). 
A Nova Lei de Migração volta o olhar para outra questão que foi sistematicamente omitida pelo estatuto anterior: as comunidades brasileiras fora do país. Além do sentido de comunidade como todos os brasileiros que se encontram fora de sua pátria, esse conceito também envolve as comunidades como grupos de convívio. Como é de conhecimento geral, não apenas congregam emigrantes legais e servem para o fortalecimento social e cultural dessas populações, como também são especiais fontes de apoio e constituição dos emigrantes desassistidos. Dessa forma, a legislação dedicou atenção específica a esses espaços, também no artigo 77, V, a partir da garantia de "ação governamental integrada, com a participação de órgãos do governo [...] visando a assistir as comunidades brasileiras no exterior" (BRASIL, 2017).

A fim de tornar célere as políticas gerais que envolvem os emigrantes, a Nova Lei de Migração também atentou para a previsão da formação de um esquema de esforço permanente para assegurar a aceleração e viabilidade do atendimento a esses cidadãos. $\mathrm{O}$ perfil desse atendimento consta no artigo 77, VI, na forma de um esforço permanente de desburocratização, atualização e modernização do sistema de atendimento, com o objetivo de aprimorar a assistência ao emigrante.

De um modo geral, as políticas públicas para o emigrante são voltadas aos problemas de recepção dos emigrantes brasileiros e o tratamento dado pelo país em sua difusão pelo mundo são ainda representativos na forma das graves prisões ilegais que, além de restringirem direitos, dificultam o retorno dos indivíduos ao seu país de origem. É reconhecido o poder-dever de punir crimes pelo Estado, da mesma forma que a proporcionalidade na restrição de direitos entre os países signatários das convenções que orientam os Direitos Humanos no tratamento desses cidadãos. Mas não são raros os casos de prisões que duram longo tempo decorrentes de migração ilegal, em uma frequente restrição à liberdade e segurança pessoal desses indivíduos (CoIDH, 1994; 1999).

Os aspectos que tornam a Nova Lei de Migração brasileira diferencial no atendimento das questões do emigrante não se restringem a essas políticas públicas de cobertura e assistência, que em muitos casos eram realizadas sem a força de lei, a partir de um conceito de atendimento 
humanitário, mas com os empecilhos temporais e de intempestividade, por não terem essa previsão. A nova legislação também apresenta um rol de garantias que no vigor da norma anterior (BRASIL, 1980) era completamente omitido: os direitos do emigrante. Tais direitos estão previstos na Seção II, e envolvem três artigos, que são discutidos em sequência: artigos 78 a 80 (BRASIL, 2017).

Embora as previsões trazidas não envolvam de todo as questões da emigração que especialmente emergem para o tratamento específico do trabalho, são providenciais para algumas garantias de interesse dos brasileiros fora do país, inclusive nas situações de retorno. No artigo 78, por exemplo, está prevista a seguinte garantia:

Artigo 78. Todo emigrante que decida retornar ao Brasil com ânimo de residência poderá introduzir no País, com isenção de direitos de importação e de taxas aduaneiras, os bens novos ou usados que um viajante, em compatibilidade com as circunstâncias de sua viagem, puder destinar para seu uso ou consumo pessoal e profissional, sempre que, por sua quantidade, natureza ou variedade, não permitam presumir importação ou exportação com fins comerciais ou industriais (BRASIL, 2017).

A garantia trazida pelo artigo 78 permite ao brasileiro que possa manter, em sua posse e conforme a situação específica de sua viagem, os produtos que sejam essenciais a um retorno sem que tenha de abrir mão de elementos que lhes sejam de importância. O fundamental é que não haja nessa preservação o sentido de comércio ou lucro envolvido, mas a permanência e persistência ao retorno de elementos que foram somados à rotina de vida e uso do viajante em retorno, para a sua volta à residência no país de origem. No artigo seguinte, artigo 79, outra previsão que procura cobrir o emigrante em condições específicas:

Artigo 79. Em caso de ameaça à paz social e à ordem pública por grave ou iminente instabilidade institucional ou de calamidade de grande proporção na natureza, deverá ser prestada especial assistência ao 
emigrante pelas representações brasileiras no exterior (BRASIL, 2017).

O artigo 79 trata de uma garantia importante para situações de calamidade em que as necessidades se somam e podem terminar colocando os emigrantes em condição de precariedade de acesso ou mesmo em segregação. Trata-se do modelo possível de assistência nessas condições, pelas representações nacionais que estejam disponíveis no exterior, a fim de que a igualdade e o acesso ao suporte também sejam assegurados ao emigrante. Na sequência, o artigo 80, que se refere diretamente às condições de trabalho que são de agravante tratamento e pouco abordadas:

Artigo 80. O tripulante brasileiro contratado por embarcação ou armadora estrangeira, de cabotagem ou a longo curso e com sede ou filial no Brasil, que explore economicamente o mar territorial e a costa brasileira terá direito a seguro a cargo do contratante, válido para todo o período da contratação, conforme o disposto no Registro de Embarcações Brasileiras (REB), contra acidente de trabalho, invalidez total ou parcial e morte, sem prejuízo de benefícios de apólice mais favorável vigente no exterior (BRASIL, 2017).

Dessa maneira, o artigo 80 é uma forma de envolver o emigrante brasileiro na cobertura dentro das condições mais paritárias possíveis no trabalho como tripulante em embarcações ou armadoras estrangeiras, de modo a procurar aproximar as duas melhores condições - a da previsão dos benefícios revistos em apólice no exterior e a garantia de sua cobertura pelo seguro previsto para embarcações brasileiras.

É uma abordagem inicial, que abre uma perspectiva para a ampliação do tratamento da ampla questão do trabalho. Sabe-se que o trabalho é uma questão em que há precarização dos emigrantes, e não há apenas reserva aos brasileiros, é comum. As frequentes crises econômicas brasileiras também motivam o êxodo de brasileiros para 
as potências mundiais que, quando em colisão com reciprocidades negativas cultural e historicamente constituídas, costumam converter à ilegalidade. As práticas ilegais nessa área, não repelem do indivíduo a sua condição humana e de dignidade, contudo, acarretam um problema adicional que necessita de mediação na garantia de direitos e proteção (MOTOKI et al., 2012).

A permanência ou as tentativas de ingresso ilegal de brasileiros em outros países são situações de extrema vulnerabilidade a esses indivíduos, quase sempre expressas na precariedade de respeito e acolhida no mercado de trabalho. Jayme (2005) descreve que, uma vez que se encontram à margem da lei, os brasileiros ilegalmente fora de seu país terminam sendo alvos de sub-remuneração e de abusos diversos, inclusive a restrição de acesso a serviços e garantias fundamentais nos países que atuam como força de trabalho. As embaixadas e vias de socorro mais usualmente buscadas também apresentam um histórico de morosidade que não costuma atender com tempestividade suas demandas.

Os objetivos da política migratória para emigrantes na Nova Lei de Migração (Lei $n^{\circ}$. 13.445/2017) se envolvem em um processo que pode ser considerado gradativo. Tem início primeiro na manifestação mundial, pela supressão da antiga normativa, de uma mudança interna no país quanto à migração e do estabelecimento de um perfil mais proativo ao emigrante. A nova lei oferece um esqueleto suficiente para o desenvolvimento de um tratamento integrado e crescente à questão de emigração, porém necessita ser iniciado de modo gradativo - a partir da fundamental reversão dos efeitos históricos do posicionamento brasileiro na questão migratória.

Oliveira (2012) afirma, sobre os movimentos que de longa data se constituem no interesse da substituição da normativa da década de 1980, que seriam produtos do interesse de igualdade e proteção do emigrante e de garantia de acesso e reconhecimento como cidadãos mundiais, de modo paritário ao que existiria em solo nacional e - se não dessa forma - igualitário ao que os preceitos humanitários indicam.

Por fim, no encerramento das discussões sobre os objetivos e perfil da política migratória para emigrantes na Nova Lei de 
Migração brasileira, é preciso destacar a visão de Nicoli (2011): em sua interpretação, o movimento feito pelo país com a aprovação da nova normativa tem a ver com o interesse de superar, com urgência, a personalidade restritiva do Estatuto do Estrangeiro da década de 1980. Esse interesse vem da necessidade de estabelecer um quadro mais positivo para o país no cenário migratório, principalmente na resposta ao que tem sido desenvolvido e praticado entre o terreno dos Direitos Humanos mundialmente disseminados e acolhidos pelos países de bom relacionamento com as maiores potências econômicas e sociais.

A postura tratada neste item seria, dessa forma, um sinalizador de desenvolvimento e paridade, que implica na retirada de formas de exclusão e discriminação do assento legal e na orientação aos pontos ratificados pelos posicionamentos internacionais dominantes sobre o tema, diretamente relacionado à busca de melhores perspectivas de trabalho, que surgem do Brasil para o mundo.

\section{Considerações Finais}

A entrada em vigor, na década de 1980, da lei que ficou conhecida como Estatuto do Estrangeiro (Lei 6.815/1980) estabeleceu uma postura endurecida, segregacionista e pouco atenta às diretrizes mundiais relacionadas à proteção ao migrante, marcados especialmente pela atenção aos Direitos Humanos.

Verificou-se que, nas últimas décadas, o Brasil passou por mudanças significativas no que se refere ao quadro das migrações internacionais, deixando de ser um grande país receptor de imigrantes para se tornar um grande país emissor de brasileiros com destino principalmente para os Estados Unidos, Europa e Japão. As questões econômicas e sociais que se estabeleceram a partir da década de 1980, com a progressão da globalização, foram determinantes na redefinição do tratamento dos estrangeiros e de sua recepção global.

Os brasileiros são uma parcela significativa dos emigrantes pelo mundo e enfrentam cotidianamente situações de desamparo e dificuldades de acesso e manutenção dos direitos quando afastados do suporte 
de redes de apoio, especialmente legais e vinculadas à sua origem. A Nova Lei de Migração brasileira, Lei 13.445/2017, foi elaborada com perspectivas de reversão à postura rígida e restritiva do Estatuto do Estrangeiro e incluiu entre seus objetivos um novo cenário de proteção ao emigrante.

No intuito de se aproximar das diversas realidades dos emigrantes, a atuação buscada pela nova lei visa à posição de um marco inicial na questão. Trata das principais situações de necessidade e cobertura, como fomento à atuação das embaixadas, fortalecimento das comunidades e o seu reconhecimento e menção normativa aos seus espaços e garantias.

A partir dessa nova orientação legal, o país não apenas entra em uma rota de reversão de sua orientação restritiva, como também sinaliza o interesse de aproximação e conexão às diretivas dos Direitos Humanos e orientações internacionais no trato da questão migratória. Para além da soberania e proteção dos Estados como ponto central, o olhar humanizado e protetivo em direitos ao imigrante e ao emigrante desenha a personalidade da Nova Lei de migração brasileira.

O Estatuto do Estrangeiro não previa qualquer orientação aos direitos e políticas públicas do emigrante, em uma espécie de "invisibilidade" normativa. Mas a Nova Lei de Migração brasileira trouxe uma situação de reconhecimento que prevê a cobertura de atenção e suporte aos emigrantes, para evitar os recorrentes casos de dilapidação da dignidade da pessoa humana e de relações espoliadoras, como as que ocorrem com frequência sobre o seu trabalho e decorrem do aproveitamento da fragilidade de indocumentados para a obtenção de lucro.

Os inúmeros casos noticiados pela mídia de prisões e tratamentos opressivos e muitas vezes abusivos oferecidos aos emigrantes brasileiros, tiveram uma duração longa a partir da dificuldade que havia legalmente de acionar a cobertura consular para essas situações. Com isso, a vulnerabilidade era ampliada e o descaso e a replicação dos problemas a outros brasileiros eram estimulados a partir de uma espécie de reconhecimento tácito de invisibilidade.

A cobertura não envolve apenas emigrantes indocumentados, mas o quadro geral desses indivíduos. Para todos é prevista a mesma cober- 
tura favorecedora de direitos e de acolhida, em especial consular, potencializando o fortalecimento desses cidadãos em suas comunidades. Em uma atitude pioneira na questão migratória, a Nova Lei de Migração brasileira estimula o desenvolvimento de pesquisas e informações para maior aproximação da realidade vivida pelos brasileiros fora de seu país, na forma de uma sinalização objetiva da pretensão de um cenário mais proativo e integrado à realidade migratória do país.

A substituição do discurso de segurança nacional vigente no Estatuto do Estrangeiro, por um discurso de direitos humanos, como propõe a nova Lei de Migração, beneficiará não só aos estrangeiros que escolham o Brasil para viver, mas também aos brasileiros que escolham viver em um país estrangeiro, vez que a legislação restritiva foi até então o principal entrave às reivindicações de direitos dos emigrantes no plano internacional.

A nova Lei traz, portanto, a expectativa de concretizar a priorização da condição do indivíduo e de sua necessidade como pessoa humana, orientando normativamente à desburocratização e melhor constituição de um sistema de atendimento eficiente à demanda do emigrante, ou seja, atentando no curto, médio e longo prazo para um tratamento de melhoria contínua da sua política migratória.

\section{REFERÊNCIAS}

BRASIL. Brasileiros em dez países podem fazer o Encceja 2017. Disponível em: <http://www.brasil.gov.br/educacao/2017/06/brasileiros-em-dez-paises-podem-fazer-o-encceja-2017>. Acesso em: 25 jul. 2017.

. Constituição da República Federativa do Brasil de 1988. Disponível em: $<$ http://www.planalto.gov.br/ccivil_03/Constituicao/Constituicao.htm>. Acesso em: 10 set. 2016.

Decreto $\mathbf{n}^{\circ}$. 7.214, de 15 de junho de 2010. Estabelece princípios e diretrizes da política governamental para as comunidades brasileiras no exterior, institui as Conferências Brasileiros no Mundo-CBM, cria o Conselho de Representantes de Brasileiros no Exterior - CRBE, e dá outras providências. 
Disponível em: <http://www.planalto.gov.br/ccivil_03/_ato2007-2010/2010/ decreto/d7214.htm>. Acesso em: 12 out. 2016.

Emenda Constitucional $\mathbf{n}^{\mathbf{0}} \mathbf{. 5 4}$, de 20 de setembro de 2007. Dá nova redação à alínea $\mathrm{c}$ do inciso I do art. 12 da Constituição Federal e acrescenta art. 95 ao Ato das Disposições Constitucionais Transitórias, assegurando o registro nos consulados de brasileiros nascidos no estrangeiro. Disponível em: $<$ http://www.planalto.gov.br/ccivil_03/constituicao/emendas/emc/emc54. htm>. Acesso em: 26 jul. 2017.

. Emenda Constitucional de Revisão ${ }^{\circ}$. 3, de 7 de junho de 1994. Altera a alínea "c" do inciso I, a alínea "b" do inciso II, o $§ 1^{\circ}$. e o inciso II do $\S 4^{\circ}$. do art. 12 da Constituição Federal. Disponível em: <http://www.planalto.gov. br/ccivil_03/constituicao/emendas/ecr/ecr3.htm>. Acesso em: 25 jan. 2017

. Lei $\mathbf{n}^{\circ} \mathbf{. 6 . 8 1 5}$, de 19 de agosto de 1980. Define a situação jurídica do estrangeiro no Brasil, cria o Conselho Nacional de Imigração. Disponível em: $<$ http://www.planalto.gov.br/ccivil_03/leis/L6815.htm>. Acesso em: 20 jul. 2017.

Lei $\mathbf{n}^{\circ}$. 13.445, de 24 de maio de 2017. Institui a Lei de Migração. Disponível em: <http://www.planalto.gov.br/ccivil_03/_Ato2015-2018/2017/ Lei/L13445.htm\#art124>. Acesso em: 20 jul. 2017.

. Ministério da Previdência Social. Acordos internacionais - português. Publicado em $1^{\circ}$. de maio de 2013. Disponível em: $<$ http://www.previdencia.gov.br/a-previdencia/assuntos-internacionais/assuntos-internacionais-acordos-internacionais-portugues/>. Acesso em: 3 nov. 2016.

. Ministério das Relações Exteriores. Consulado-Geral do Brasil em Hamamatsu. Espaço do Trabalhador Brasileiro, atualizado em 01/02/2016. Disponível em: <http://hamamatsu.itamaraty.gov.br/pt-br/espaco_do_trabalhador_brasileiro_etb.xml>. Acesso em: $1^{\circ}$. nov. 2016.

. Tribunal Superior Eleitoral. Cresce o número de eleitores brasileiros que poderão votar no exterior, 2 de junho de 2014. Disponível em: $<$ http:// www.tse.jus.br/imprensa/noticias-tse/2014/Junho/cresce-o-numero-de-eleitores-brasileiros-que-poderao-votar-no-exterior>. Acesso em: 4 jun. 2016.

CORTE INTERAMERICANA DE DERECHOS HUMANOS. Caso Castillo Petruzzi y otros vs. Peru, Sentença de 30 de maio de 1999. Disponível em: 
$<$ http://www.corteidh.or.cr/docs/casos/articulos/seriec_52_esp.pdf $>$. Acesso em: 17 jul. 2017.

Caso Gangaram Panday vs. Suriname. Sentença de 21 de janeiro de 1994 Disponível em: <http://www.corteidh.or.cr/docs/casos/articulos/ seriec_16_esp.pdf>. Acesso em: 17 jul. 2017.

. Parecer Consultivo OC-21/14, de 19 de agosto de 2014, solicitado pela República Argentina, República Federativa do Brasil, República do Paraguai e República Oriental do Uruguai. Disponível em: <http://www. corteidh.or.cr/docs/opiniones/seriea_21_por.pdf>. Acesso em: 3 ago. 2016.

FARIA, Maria Rita Fontes. Migrações internacionais no plano multilateral: reflexões para a política externa brasileira. Brasília: Fundação Alexandre de Gusmão, 2015.

GALEANO, Eduardo. Os mapas da alma não têm fronteiras. Carta Maior. Internacional. 13 jul. 2009. Disponível em: <http://www.cartamaior.com. br/?/Editoria/Internacional/Os-mapas-da-alma-nao-tem-fronteiras/6/15008>. Acesso em: 10 mai. 2017.

JAYME, Erik. O Direito Internacional Privado do novo milênio: a proteção da pessoa humana face à globalização. In: ARAUJO, Nadia de; MARQUES, Cláudia Lima (Orgs.). O novo Direito Internacional: estudos em homenagem a Erik Jayme. Rio de Janeiro: Renovar, 2005, p. 2-15.

LACERDA, Nádia Demoliner. Migração Internacional a trabalho. São Paulo: LTr, 2014.

MARGOLIS, Maxine L. Goodbye, Brazil: emigrantes brasileiros no mundo. Tradução de: Aurora M. S. Neiva. São Paulo: Contexto, 2013.

MOTOKI, Carolina et alli. Migração: o Brasil em movimento. São Paulo: Copyleft, 2012.

NICOLI, Pedro Augusto Gravatá. A condição jurídica do trabalhador migrante no direito brasileiro. São Paulo: LTr, 2011.

OLIVEIRA, Francisco Antônio de. Curso de Direito do Trabalho. São Paulo: LTr, 2012.

ORGANIZAÇÃO INTERNACIONAL PARA MIGRAÇÕES. Perfil migratório do Brasil 2009. Brasília: Ministério do Trabalho, 2010. 
PÁDUA, Luciano. A nova rota dos brasileiros no exterior: enquanto a emigração para destinos tradicionais tem decaído nos últimos anos, o fluxo de brasileiros para países com políticas de atração para a mão-de-obra aumenta. Veja. 7 abr. 2015. Disponível em: <http://veja.abril.com.br/brasil/a-nova-rota-dos-brasileiros-no-exterior/>. Acesso em: 11 mai. 2017.

REIS, Rossana Rocha. A política do Brasil para as migrações internacionais. Contexto internacional, vol. 33, n. 1, jan./jun. 2011. Disponível em: $\quad<$ http://www.scielo.br/scielo.php?script=sci_arttext\&pid $=$ S0102-85292011000100003 $>$. Acesso em: 13 mai. 2015 .

SANTOS, Eduardo dos. A questão migratória no mundo globalizado - brasileiros no exterior, a emigração e o retorno. In: PRADO, Erlan José Peixoto; COELHO, Renata. Migração e trabalho. Brasília: Ministério Público do Trabalho, 2015, p. 69-78.

SPRANDEL, Marcia Anita. Breve análise da relação entre o Estado brasileiro e seus emigrantes. In: FERREIRA, Pacelli Ademir et allii. A experiência migrante: entre deslocamentos e reconstruções. Rio de Janeiro: Garamond, 2010. VEDOVATO, Luís Renato. O direito de ingresso do estrangeiro: a circulação das pessoas pelo mundo do cenário globalizado. São Paulo: Atlas, 2013.

\section{SOBRE OS AUTORES}

\section{Ana Paula Martins Amaral}

Mestre e doutora em Direito pela Pontifícia Universidade Católica de São Paulo (PUC/SP), realizou estágio de pós-doutorado na Universidade Federal de Santa Catarina (UFSC). Professora associada da Universidade Federal de Mato Grosso do Sul (UFMS) em Campo Grande/MS.

CV: http://lattes.cnpq.br/2909148996309717

E-mail: ana.amaral@ufms.br 


\section{Luiz Rosado Costa}

Mestrando em Direitos Humanos pela Universidade Federal de Mato Grosso do Sul.

CV: http://lattes.cnpq.br/6850285493583530

E-mail: luizrosadocosta@gmail.com

\section{Cristiane Batista Arrua Allgayer}

Mestranda em Direitos Humanos pela Universidade Federal de Mato Grosso do Sul.

CV: http://lattes.cnpq.br/7904987711630497

E-mail: cristianeallgayer.adv@gmail.com

Submetido em: 1-8-2017

Aceito em:13-11-2017 